\title{
TŘI POSTAVY SOUČASNÉ FENOMENOLOGIE VE FRANCII A OTÁZKA KORELAČNÍHO A PRIORI
}

\section{Petr Prášek}

\section{Úvod}

Když Jean-Luc Marion reaguje na knihu o nové fenomenologii ve Francii, ${ }^{1}$ navrhuje další možnou cestu, kterou bychom se v rámci pokusu psát o jedné větvi současné fenomenologie mohli vydat: „Myslím, že namísto bodů, v nichž se rozcházejí, by bylo lepší pokusit se přesně ukázat několik rozhodnutí, která by umožnila redefinovat sít', v níž každý z vybraných autorů hraje nějakou roli."2 Náš text se inspiruje tímto návrhem. Pokoušíme se v něm predstavit a zároven̆ na pozadí jediného fenomenologického pole, jež postupně načrtáváme, konfrontovat tři představitele současné fenomenologie ve Francii: Renauda Barbarase, Jeana-Luca Mariona a Marca Richira. Marion a Richir jsou možná největší současní francouzští fenomenologové, kteří již své myšlení systematicky rozvinuli, nebo dokonce dovršili. ${ }^{3}$ Barbaras je člen generace mladší, avšak zároveň již autor originálního a bezpochyby inspirujícího projektu, který nám díky svému tázání po korelačním a priori umožní propojit naše bádání s klasickou fenomenologií Edmunda Husserla.

Problém korelačního a priori nás v tomto pokusu bude vést a současně s tím bude i nutným omezením. Již předchůdci našich autorů (např. Maurice Merleau-Ponty, Emmanuel Lévinas, Michel Henry) analyzovali fenomény, jež není možné popsat (pouze) intencionálně a jimž musíme připsat určitou autonomii. Když László Tengelyi shrnuje svá bádá-

1 H. Gondek - L. Tengelyi, Neue Phänomenologie in Frankreich, Berlin 2011.

2 J.-L. Marion, Quelques précisions sur la réduction, le donné, l’herméneutique et la donation (= Quelques précisions), in: Ch. Sommer (vyd.), Nouvelles phénoménologies en France, Paris 2014, str. 217.

3 M. Richir (zemřel v listopadu 2015) byl fenomenologem belgického původu, který od roku 1976 žil na jihu Francie a který - jak ukážeme ve třetí části tohoto textu - má v současném francouzském fenomenologickém myšlení své pevné místo. 
ní o této spontaneitě, hovoří o „událostním rázu“ jevení. ${ }^{4}$ Jde o výraz zastřešující vícero charakteristik fenoménu: spontánní utváření smyslu, ne-objektivní přesah, iniciativa daného atd. Musíme ovšem zdůraznit, že žádné takové určení nás nezbavuje nutnosti myslet na základě korelace: Fenomenologie - jakožto specifický typ myšlení nacházející se mezi idealismem a realismem ${ }^{5}$ - musí vždy s nějakou korelací počítat, třebaže byla ta husserlovská nahrazena korelací hlubší, která oné autonomii fenoménů odpovídá lépe. Tři podoby této ,post-klasické“ korelace budou předmětem následujícího výkladu.

\section{Barbaras, fenomenologie jako hledání korelačního a priori}

Od chvíle, kdy se Husserlova fenomenologie stala transcendentální (tím, že dík epoché odkryla sféru redukovaného vědomí, jež se intencionálně otevírá světu), je jejím hlavním předmětem právě korelace mezi čistými prožitky vědomí a věcí skrze ně se jevící. Jinými slovy: Jelikož je fenomenologie ,vědou“ o fenoménech a jelikož, jak říká Husserl, „slovo ,fenomén“ je dvojznačné díky podstatné korelaci mezi jevením se a tím, co se v tomto jevu jeví“, 6 musí se chápat jakožto zkoumání universálního korelačního a priori, čili obecnosti (typiky), která vládne čistému vědomí a která řídí konstituci všeho toho, co se v něm jeví. ${ }^{7}$

$\mathrm{R}$. Barbaras říká, že je fenomenologem v té míre, v níž toto korelační a priori dále rozpracovává. Počátky jeho vlastního fenomenologického projektu lze datovat přibližně do roku 1994, kdy byla vydána kniha Vnímání (Esej o smyslově vnímatelném). Barbaras v ní však klasické pojetí korelace odmítá, nebot' je v něm celá váha jevení nesena jedním

4 Tengelyi shrnuje tyto charakteristiky v článku New Phenomenology in France, in: The Southern Journal of Philosophy, 50, 2012, str. 295-303.

5 R. Barbaras popisuje postavení fenomenologie velmi pěkně: „Jelikož je jsoucí v podstatném vztahu k vědomí, nemůže spočívat samo v sobě jako nějaká realita o sobě; avšak v té míře, v níž jsoucí přesto v tomto samém vztahu zůstává transcendentní - což znamená, že jde o pouhý vzájemný vztah (,corrélation“) a nikoli o ztotožnění -, jeho realita nemůže být pohlcena realitou vědomí, jak by tomu chtěl idealismus.“ R. Barbaras, La vie lacunaire, Paris 2011, str. 113-114.

6 E. Husserl, Idea fenomenologie, přel. M. Petř́iček - T. Dimter, Praha 2001, str. 24.

7 Srv. E. Husserl, Krize evropských věd a transcendentální fenomenologie, přel. O. Kuba, Praha 1972, §§ 46-48. 
ze členů relace, subjektem, či spíše absolutním bytím subjektivních prožitků (a především konstituujícími noesemi), které zajišt’ují celý vztah k transcendentnímu objektu, de iure plně určitelnému. Barbaras tvrdí, že Husserl touto teorií zradil svi̊j vlastní fenomenologický objev, jímž je „nastiňování“, které dosvědčuje původní autonomii fenomenálna, a tedy neredukovatelnost problému vnímání na problém poznání objektu. ${ }^{8}$ To, co se původně jeví, zcela přesahuje řád objektů i jsoucího, je v neustálém nadbytku vůči tomu, jak je $\mathrm{v}$ jevech (nástinech) prezentováno (ačkoli zároveň platí, že tyto jevy nepředchází). Jde o samu čistou transcendenci každého jednotlivého transcendentního jsoucna, o svět $\mathrm{v}$ jeho nejhlubším fenomenologickém smyslu. ${ }^{9}$ Barbaras se tedy snaží hledat korelaci, která by odpovídala jevení samému, jehož podstata spočívá v ústupu původní instance jevení, kterou je svět, v jeho hloubce, nezrušitelném odstupu. Vychází tedy z husserlovského problému a na pozadí fenoménu světa neredukovatelného na jsoucí v něm obsažené hledá jeho transcendentální podmínky, „, a priori husserlovského a priori“ ${ }^{\text {“ }}{ }^{10}$ Pěkně to shrnuje Etienne Bimbenet:

„[Barbaras] vychází z fenomenologické výpovědi, podle níž transcendentní jsoucí spojuje se subjektivními způsoby jeho jevení nutná korelace, a snaží se transcendentálně vykázat její podmínky možnosti. Uchopuje tedy takř́íkajíc eidos (nutný výraz) zkušenosti, aby se následně - vyzbrojen touto podstatnou nutností - pustil hlouběji ve směru zkoumání způsobu bytí této zkušenosti. Jestliže je tato korelace čímsi pravdivým, a tak tomu nepochybně je, jaký způsob bytí musí potom příslušet jak subjektu jevení, tak jevícímu se jsoucímu?"11

To je základní otázka, která se opakovaně vynořuje v Barbarasových knihách a na niž odpovídá již ve zmiňované eseji o vnímání, čímž nám svěřuje svůj program na následujících dvacet let filosofické práce: Subjekt vnímání je nutné myslet jako živou bytost a vnímané jako svět. ${ }^{12}$

8 Srv. R. Barbaras, Vnímání (Esej o smyslově vnímatelném), přel. J. Fulka, Praha 2009 , str. 38-42.

9 Srv. R. Barbaras, Sauver d'une réification de la conscience. La tâche de la phénoménologie, in: Les études philosophiques, 100, 2012, str. 55-56.

10 R. Barbaras, Dynamique de la manifestation, Paris 2013, str. 7.

11 É. Bimbenet, Le seul absolu, c'est la phénoménalité même, in: Ch. Sommer (vyd.), Nouvelles phénoménologies en France, Paris 2014, str. 138.

12 Srv. R. Barbaras, Vnímání (Esej o smyslově vnímatelném), str. 43. 
Nejsystematičtější rozpracování tohoto úkolu nacházíme v Úvodu do fenomenologie života. ${ }^{13}$ Základní analýza korelace Barbarasovi ukázala, že její pravý subjekt, subjekt přináležející ke světu a zároveň od něho odlišný, aby jej mohl fenomenalizovat, je nekončící pohyb směrem ke světu, Touha jakožto podstata žití ve dvojím smyslu Leben i Erleben, ve smyslu být naživu (živoucí pohyb) i prožívat (vědomí). ${ }^{14}$ Je tedy nutné zdůraznit, že pod pojmem touhy překračujeme všechny „ekvivoční“ pojmy snažící se uchopit subjekt v nějaké míře odlišný či nezávislý na svém objektu (Husserl) a rovněž i všechny pojmy „univoční“ popisující sféru, k níž oba náleží (Merleau-Ponty). Dokonce i vzhledem ke krajní opozici mezi realismem a idealismem se touha jakožto výraz fenomenologie situuje jaksi mimo: Touha totiž znamená obojí naráz, oba aspekty korelace i střední pozici fenomenologie. Jde o transcendentální určení způsobu bytí subjektu na základě původního (korelačního) pohybu jevení samého. Tím, že se subjekt jakožto touha realizuje, zakládá jak svou přináležitost ke světu, tak svou odlišnost od něj:

„Jakožto subjekt touhy je subjekt v srdci světa, tvořený stejným materiálem jako on, a současně je od světa odlišný, jelikož je to právě Touha hledající své naplnění, která objevuje přesah, jímž je, jelikož se tím, že se takříkajíc činí světem, subjekt navrací k sobě samému, zakládá svou nezrušitelnou odlišnost od světa." 15

V pozdějších knihách a zejména ve svém díle Dynamika manifestace Barbaras pokračuje v určování smyslu bytí jsoucen ve vzájemném vztahu. Další objasňování obou aspektů korelace, tj. přináležitosti a odlišnosti, ho však nutí překročit rámec fenomenologie. Uvažování o touze nás totiž vede př́mo $\mathrm{k}$ ontologickému pojmu světa a k nové fenomenologické disciplíně - kosmologii. Z určitého pohledu se jedná o jakýsi návrat $\mathrm{k}$ přirozenému postoji, $\mathrm{v}$ němž svět jest. Jde však o návrat pres fenomenologii a to, k čemu se tedy vracíme, je svět ,založený“ fenomenologicky, svět transcendentálně vyvozený v mezích korelace. Jelikož se touha uskutečňuje prostřednictvím světa, v němž spočívá její vlastní bytí (je pohybem ke světu), je z toho třeba vyvodit, že mezi nimi existuje jistá ontologická prribuznost:

13 R. Barbaras, Introduction à une phénoménologie de la vie, Paris 2008.

14 Srv. tamt., str. 255-256.

15 Tamt., str. 360. 
„To, co podstata touhy odhaluje, je, že subjekt je tvořen ze stejného materiálu jako svět, že je za jejich zjevným odstupem určitá hluboká ontologická kontinuita ... Poznamenejme, že jsme přesně v tomto bodě opustili rámec fenomenologie a vstoupili do ontologie: Prošli jsme takř́ikajíc nad korelací subjektu a světa, abychom dospěli k rovině, na níž se osvědčuje jejich společné bytí."16

Ba co víc, jestliže je subjekt takto ze světa a jestliže je pohybem, je jasné, že i svět bude muset být nějakým dynamismem, že existuje jistý proces světa jakožto řecké fysis, dění světa (předmět oné kosmologie), do něhož je náš subjektivní fenomenalizující pohyb pevně začleněn. Ačkoli se na první pohled může zdát, že zde Barbaras překračuje hranice fenomenologie spekulativně, není tomu tak. To, čemu ř́ká pra-pohyb (archi-mouvement) světa, je v prvním kroku úvahy jen jakýmsi zrcadlovým obrazem pohybu touhy čili pohybem touhy viděným z pohledu druhého pólu korelace, tj. z pohledu světa: Dění světa je obsahově vymezeno tím, co se nám jeví a jevit může, ačkoli je to ve své konkrétnosti nepředpověditelné. ${ }^{17}$ Druhý krok úvahy poté spočívá v jakémsi osamostatnění tohoto pohybu od pohybu subjektu, a ani v něm se nejedná o žádnou spekulaci, nebot' svět opravdu není totožný s tím, co se z něj subjektu jeví: Svět tento obsah subjektivní zkušenosti vždy přesahuje. Barbaras tak může hovořit o kosmologii proto, že je svět transcendencí, či - jak sám říká - ještě nediferencovaným temným Podkladem (Fond). ${ }^{18}$ Tento svět se subjektu jeví díky tomu, že je ve své podstatě touhou, která je s ním př́buzná. Jinak řečeno, pohyb světa a pohyb touhy jsou fenomenologicky jaksi na stejné rovině: Platí sice, že svět je vždy v nezrušitelném odstupu od subjektu, avšak tento odstup je ihned kompenzován touhou v jeho jádru. Barbaras tak hovoří o novém, hlubším smyslu přináležitosti; nejde o zahrnutí či umístění, subjekt jakožto touha neobývá ve světě žádné místo. Vposled jde o jakýsi ontologický pra-pohyb (archi-mouvement) či pra-život (archi-vie), na němž subjekt jakožto touha participuje. Tento pohyb je tak poslední transcendentální podmínkou přináležitosti subjektu ke světu, podmínkou, která nám vysvětluje původ nějakého světa naší subjektivní zkušenosti, plné různých typů jsoucen a podléhající neustálé změně:

\footnotetext{
16 R. Barbaras, La vie lacunaire, str. 149.

17 Srv. R. Barbaras, Métaphysique du sentiment, Paris 2016, str. 24-25.

18 Tamt., str. 27-34.
} 
„Tento pra-pohyb je neustávající přechod světa jakožto Podkladu (Fond) ke světu jakožto multiplicitě jsoucen skrze diferenciaci Podkladu: je to proces konstituce jsoucího skrze individuaci Podkladu ... Tento proces individuace pochopitelně nikdy nevyčerpá sílu Podkladu, a proto pokračuje uvnitř světa $\mathrm{v}$ podobě pohybů postihujících jsoucí. Jsoucna nejsou nikdy plně individuována, nýbrž se stále individuují..." "19

Nutným důsledkem potom musí být rozlišení dvou úrovní manifestace: 1) manifestace jakožto diferenciace je dílem světa, kdežto 2) manifestace jakožto odkrývání toho, co vyprodukoval svět, je uskutečňována subjektem. Navzdory tomu, že jsme odkryli naprostý základ, ontologický pra-pohyb manifestace, řekli jsme tedy jen polovinu pravdy. Zbývá nám totiž ještě vysvětlit, co $\mathrm{v}$ transcendentálním poli odpovídá odlišnosti subjektu a světa. Musíme se od toho, co je touze a světu společné, dostat ke genezi subjektu husserlovské korelace. Stejně jako Merleau-Pontyho ontologický pojem „tělesnost“" (chair) nedostačuje k adekvátnímu vysvětlení korelace, tak ani korelační a priori nemůže být dovršeno pra-pohybem, nebot', ,je nemožné projít cestu, jež nás dovedla k pra-pohybu, opačným směrem“ a ukázat zrození oné diference uvnitř tohoto pohybu. ${ }^{20}$ Subjekt se zajisté rodí ve světě (to znamená, že vše, co se nám jeví, je dílem světa), avšak zároveň není jako ostatní jsoucna, která jsou pra-pohybem produkována: Subjekt ztratil svět a je schopen se proti němu postavit; v podobě jednoho pólu korelace $v \check{d} d y$ již doprovází pra-pohyb světa. Z tohoto důvodu je Barbaras nucen postulovat kamsi doprostřed pra-pohybu, v němž této ztrátě jinak nic nenasvědčuje, jakousi metafyzickou pra-událost (archi-événement), která je dostatečným důvodem naprosto minimální, ale současně nevyhnutelné odlišnosti subjektu uprostřed světa. ${ }^{21}$ Událost tudíž musí být metafyzická z prostého důvodu: „P P̛osobi na pra-život, ale nepřináleži k němu.“22 Barbaras ovšem nezamýšlí osvětlovat status této události v nějaké metafyzice klasického typu. Jeho pra-událost je naprosté minimum, jež je nutno předpokládat

19 R. Barbaras, La vie lacunaire, str. 152-153.

20 Tamt., str. 155. V článku věnovaném pojmu „,chair“ Barbaras říká: „Merleau-Ponty klade důraz na univoční pojem chair, k němuž musí moci být vztažena sama distinkce pocit'ujícího a pocitovaného, tedy nakonec intencionální odstup." (Tamt., str. 20.)

21 Srv. R. Barbaras, Dynamique de la manifestation, str. 272.

22 R. Barbaras, La vie lacunaire, str. 157. 
proto, aby fenomenologie, jejímž základním výrazem je korelace, mohla existovat:

„Přri přechodu od kosmologie k metafyzice nepřecházíme od procesu k tomu, co ho vposled zakládá. Vracíme se spíše od tohoto procesu $\mathrm{k}$ fenomenologické korelaci, a to díky objevu její vlastní nekonzistence neboli jejího vnitřního zhroucení. Je to právě tato slabost či křehkost v srdci procesu, která je nikoli základem, ale metafyzickým rubem fenomenologie v lůně kosmologie.“23

Jestliže je tedy úkolem fenomenologie vypracování universálního a priori korelace mezi vědomím a světem, pak lze říct, že ho Barbaras plní v celém rozsahu. Jeho Dynamika manifestace se svými třemi oddíly „fenomenologie, kosmologie, metafyzika“ popisuje, jak může subjekt nechat svět jevit se, tedy to, jak subjekt přináleží ke světu, aniž by to jakkoli narušilo jejich odlišnost nezbytnou k tomu, aby jejich vztah byl vztahem fenomenalizace. To, co Barbarase odlišuje od ostatních fenomenologů, je právě toto jeho urputné sledování logiky korelace. Důsledkem je, že každá jeho fenomenologická analýza bude mít vždy nevyhnutelně dva aspekty: Bude se soustředit jak na to, co v daném fenoménu odpovídá pra-pohybu světa, tak i na to, co zde odpovídá pra-události naší separace. Abychom dali př́klad: Ve svých aktuálních bádáních o smyslově vnímatelném, v nichž se snaží uchopit klíčový vztah mezi smyslem bytí uchovávajícím hloubku světa a řečí, bádáních o poezii, která se zdá být jako jediná schopna artikulace této hloubky, si uvědomil nutnost hledat u bytostí, které jsou od světa radikálně odděleny, jejich prostředek komunikace. Jeho pocit (sentiment), jediná půda pravé poezie, tedy není žádný počitek, nějaká složka vnímání, které je vždy již spjato se světem objektů, ani žádná naše schopnost: Jde o ontologickou dimenzi, jíž ke světu přináležíme navzdory separaci, opět tedy obojí naráz. ${ }^{24}$

Přinejmenším pro tuto chvíli se tak Barbaras nijak nehodlá pouštět do odděleného zkoumání pra-pohybu či pra-události, aby mohl hovořit např. o konkrétních událostech pra-pohybu, protože na rovině fenomenologie, tj. na rovině korelace, je svět jako takový (pra-pohyb) v ústupu ve prospěch věcí, které z něj vyvstávají díky pra-události naší separace. Pra-pohyb je vždy již postižen pra-událostí. Plyne z toho, že onen ne-ob-

23 R. Barbaras, Dynamique de la manifestation, str. 299.

24 Tuto teorii pocitu rozvíjí Barbaras v nedávno vydané knize Métaphysique du sentiment, str. 177-195. 
jektivní přesah, který se nachází v centru zájmu současné fenomenologie ve Francii, není jako takový uchopitelný ani po seberadikálnější epoché. Barbaras ř́ká, že jsme v situaci saturace slepí, což znamená, že jsme od pra-pohybu, který saturuje, odstřiženi. Pro fenomenologa existuje pouze jeden způsob, jak uchopit onen neviditelný „nadbytek“ vlastní autonomii fenoménu, a tím je skrze analýzu způsobu bytí subjektu odkaz na $a b$ straktni pra-pohyb, na jeden $\mathrm{z}$ aspektů korelace. To je prrirozený limit fenomenologie postupující důsledně podle logiky korelace. Veškeré možné zkoumání pra-pohybu je do budoucna u Barbarase výrazně omezeno na to, co se $\mathrm{z}$ něho uchovává $\mathrm{v}$ našem pocitu (sentiment).

Pokud tedy chceme zkoumat spontánnost fenomenálna v nějaké konkrétní analýze (tváře, obrazu atd.), budeme se muset stát nesmírně pohyblivými, protože jinak nebudeme schopni uchopit to, co je stále na ústupu. Přejděme proto nyní k jiné fenomenologické strategii, k jinému fenomenologovi, který se ve své snaze začlenit do fenomenologie to, čemu ř́íká saturovaný fenomén, zdá být úspěšný - k Jeanu-Lucu Marionovi.

\section{Marion, dávání jakožto podstata fenoménu}

Ne-objektivní přesah fenoménu je explicitně tematizován i ve fenomenologii dávání: ,... ve fenomenologii již vůbec nejde o to, co subjektivita vnímá tím či oním perceptivním nástrojem, ale prímo o to, co - skrze ně, navzdory nim, ba dokonce bez nich - jevení dává samo ze sebe a jako věc samu.“25 Jestliže Barbaras sleduje jevení samo za pomoci nového fenomenologického pojmu světa a související otázky po způsobu bytí subjektu v tomto světě, pak Marion odkrývá podobným způsobem, tj. v hloubce Husserlovy korelace, jedinou instanci: Subjektivní mody jevení (na straně vědomí) a jevící se jsoucí (na straně transcendence) korelují v jediném dávání fenoménu samého, ,to první je jakožto dané dáno skrze a podle toho druhého, dávání samého (la donation elle-même)““. 26

Jako kdyby tím Marion nechal dosud vyváženou barbarasovskou korelaci převážit ve prospěch světa, a to především v jeho neuchopitelném aspektu, ve prospěch jeho ustupování, v němž spočívá celá jeho autonomie. Takový výklad podporuje i Marionův pojem světa, který byl rozpracován teprve nedávno v článku věnovaném Patočkovi: Svět jakož-

25 J.-L. Marion, Étant donné, Paris 2013, str. 12.

26 J.-L. Marion, De surcroît, Paris 2010, str. 25. Zvýraznil P. P. Srv. také Étant donné, str. 38. 
to ,jsoucí-dané v celku“ (l'étant-donné en totalité), které se neukazuje, podléhá dávání, které ho řídí; $v$ prrípadě světa nejde prrísně vzato o instanci dávání samého. ${ }^{27}$ Plyne z toho, že - pokud lze u Mariona vůbec mluvit o nějaké korelaci - jde o korelaci silně asymetrickou mezi jevením a dáváním, a proto výraz korelace není príliš vhodný. ${ }^{28}$ Vztah mezi jevením a dáváním je totiž charakterizován tím, že jev se jeví jen v té míře, v níž se dává. Aby však mohla být řeč o korelaci, nesměla by být „subjektivní“ část vztahu zcela redukovatelná na druhou část, tj. dávání, čemuž u Barbarase brání pra-událost oddělení subjektu od světa. Proto je nutno uzavřít, minimálně na první pohled, že Marion uzávorkovává vše, co se netýká dávání, všechno to, co nás od něj odvrací - a to je přesně odlišnost v jádru subjektu. Odtud jistá asymetrie. ${ }^{29}$

Nicméně právě to je důvod, proč jsme se k Marionovi obrátili: Jelikož důsledně nesleduje korelaci a soustředí se na zdroj nezávislosti fenomenálna, jejíž jádro spočívá v dávání, hledá tím způsob, jímž je možno tento zdroj zkoumat i v momentě, v němž je u Barbarase na ústupu. Nechejme přitom prozatím stranou otázku oprávnění takového projektu, čili oprávnění snahy klást důraz na jeden z členů korelace.

To, co nás má $\mathrm{k}$ dávání dovést, je redukce, ${ }^{30}$ což Marion vyjadřuje $\mathrm{v}$ podobě prvního (či posledního) principu fenomenologie „kolik reduk-

27 Srv. J.-L. Marion, Le visible et le révélé, Paris 2005, str. 92; a J.-L. Marion, La donation, dispense du monde, in: Philosophie, 118, 2013, str. 90. É. Tardivel označuje svět za instanci dávání nepřesně. Srv. É. Tardivel, Monde et donation. Une révision du quatrième principe de la phénoménologie, in: Revue de Métaphysique et de morale, 120, 2015, str. 129. Je sice pravda, že svět, „dává“ dané, ale činí tak jen jako ,jsoucí-dané v celku“, takže tu stále zůstává odchylka, pro Mariona klíčová, mezi světem a dáváním. Kvůli této odchylce dokonce Marion v posledním textu věnovaném pojmu světa označení ,jsoucí-dané v celku“ (l'étant-donné en totalité) reviduje, jelikož svět žádným celkem (totalitou) není: Přesně řečeno je netotalizovatelnou a nepředvídatelnou rezervou daného. Srv. J.-L. Marion, Reprise du donné, Paris 2016, str. 144-146.

28 Proto nakonec nemůžeme souhlasit s Á. Tákácsem, ačkoli na asymetrii upozorňuje rovněž. Srv. Á. Tákács, L'idée de corrélation et la phénoménologie de l'objet chez Jean-Luc Marion, in: S. Camilleri - Á. Tákács (vyd.), Jean-Luc Marion: Cartésianisme, Phénoménologie, Théologie, Budapest 2012, str. 61-73.

29 Zde vidíme oprávněnost některých námitek D. Janicauda, podle kterého si Marion nevšímá druhé části definice fenoménu u Heideggera, v níž se mluví o ústupu světa. Výsledkem je pak podle Janicauda „maximalistická koncepce fenomenologie“. Srv. D. Janicaud, La phénoménologie éclatée, Paris 1998, postupně str. 65 a 15 .

30 Musíme poznamenat, že tato redukce, u níž se bohužel často mylně předpokládá spjatost s metodou klasické fenomenologie (s redukcí jakožto metodickým 
ce, tolik dávání“ (autant de réduction, autant de donation). ${ }^{31}$ Redukovat něco na dané znamená „vidět“ to jako dávající se, vyloučit z jevení všechno to, co se bezvýhradně nedává. Př́íklad z Étant donné: Obraz je třeba nechat, aby se sám prosadil, je třeba ho redukovat na „účinek jako otřes, který působí viditelné, účinek jako dojetí zaplavující pozorujícího, účinek jako nepopsatelnou kombinaci tónů a linií, který neredukovatelně individualizuje představení. Tato komplexita smíšených účinků dosvědčuje, že se prosazuje autonomní a neredukovatelný smysl - účinek smyslu, označující vlastní půdu, z níž se jakoby ze sebe vynořuje viditelnéc.32 Je jasné, že takto redukovaný obraz není žádným plně konstituovaným objektem. Ačkoli platí, že je dán, chybí mu určitost. Přijmout dané jakožto dané tudíž znamená pochopit ho na základě jakéhosi tajemného záhybu dávání, který je oním ne-objektivním přesahem a který tu neoddiskutovatelně probleskuje právě skrze onu „komplexitu účinkư“, skrze jejich nekontrolovatelnou distribuci, skrze nemožnost myslet to, co je tu k myšlení, ihned nebo naráz. ${ }^{33}$

Tímto způsobem Marion rozvíjí, jak sám říká, to, co Heidegger ponechává ze své definice fenoménu nemyšleno: ${ }^{34} \mathrm{~V}$ oné odchylce mezi daným a dáváním nachází zdroj fenoménu jevícího se ze sebe. Činí tak v kontrastu ke klasickým definicím, které fenomén podřazují (a tím ho již omezují) podmínkám poznání, a to především pojmu, nebot' to, co je důkazem jeho spontaneity, spočívá naopak v jeho vnitřním určení spjatém ve většině př́padů s dávajícím názorem. ${ }^{35} \mathrm{Je}$ sice pravda, jak víme od Kanta, že názor bez pojmu zůstává slepý, stejně jako pojem bez názo-

krokem subjektu, kterým se prožitky empirického ego převádějí na prožitky čistého transcendentálního ego), byla několikrát kritizována. Srv. např. C. Romano, Remarques sur la méthode phénoménologique dans Étant donné, in: Annales de philosophie, 21, 2001, str. 6-13, nebo É. Tardivel, Monde et donation. Une révision du quatrième principe de la phénoménologie, str. 121-136. Důvodem nejasností okolo redukce byl rovněž fakt, že se Marion dlouho nezabýval rozdílem mezi epoché a redukcí, který se stal explicitně jeho tématem až v jednom článku z roku 2015, jenž vyšel v přepracované verzi rovněž v jeho nejnovější knize. Srv. J.-L. Marion, Reprise du donné, str. 51-56.

31 J.-L. Marion, Étant donné, str. 23-30.

32 Tamt., str. 83.

33 Srv. J.-L. Marion, Quelques précisions, str. 224.

34 „To, co se ukazuje, něco ukazujícího se ... to, co se ukazuje samo o sobě, co je zřejmé.“ M. Heidegger, Bytí a čas, přel. I. Chvatík - P. Kouba - M. Petř́iček J. Němec, Praha 2008, str. 45.

35 Nejde však o dávající intuici Husserlovu, která je podle Mariona rovněž omezením původní fenomenality. A musíme zde rovněž dodat, byt' jde o minimum 
ru prázdný, „ovšem slepota je lepší než prázdnota: ačkoli je slepý, názor stále dává, zatímco pojem, byt' on jediný nám umožňuje dané vidět, zůstává jako takový dokonale prázdný, a tedy i neschopen cokoli vidět‘“.36 Novou normativní figurou fenomenologie se tak stává zcela osvobozený fenomén, tj. fenomén myšlený nezávisle na všech podmínkách poznání, pouze s ohledem na to, jak se sám dává, kterému Marion - kvůli převaze názoru, jíž neodpovídá žádný pojem - říká saturovaný fenomén. Většina fenoménů našeho života se totiž může stát místem saturace. ${ }^{37}$ Takové fenomény sice mohou být, a skutečně i jsou, pojmově myšleny či vyslovovány, jsou pro nás objekty mezi jinými (jako např. onen obraz v nějakém umělecko-historickém pojednání), avšak ani zdaleka se tím nevyčerpává to, čím jsou samy ze sebe. Marion tedy rozhodně nechce popírat objektivní fenomény, jeho úmyslem je vyzdvihnout, že stejně tak, a to dokonce především, máme zkušenost jakéhosi „ne-objektivního“ fenoménu, čili onu zkušenost přebytku nad objektivitou, nad běžným pojmem zkušenosti. Proto mluví o saturaci objektivních fenoménů: „... jestliže váháme nad formulací nějaké pozitivně ne-objektivní zkušenosti, pak budeme hovořit o tom, co se - odporujíc podmínkám zkušenosti - jeví po způsobu jejich saturace v jakési kontra-zkušenosti.“38

Saturace má dokonce ten důsledek, že objekt jaksi přestává být viditelný, nebot' saturující názor, bez přestání cosi přidávající, překrývá obrysy viditelného. To nás činí slepými a schopnými vidět jen za předpokladu, že přijmeme to, co se ze sebe samého dává. Jde takřka o opačnou slepotu než u Barbarase, u něhož jsme slepí vůči pra-pohybu světa, který saturuje, ale vidíme z něj se vydělující objekty. U Mariona, který provádí redukci na to, co saturuje, jsme naproti tomu slepí vůči viditelným objektům samým, které lze vidět - ovšem nyní již v souladu s tím, jak saturují - pouze za té podmínky, že je přijmeme jako saturované, jako dávající se. Toto prijetí nás vede nevyhnutelně ke stále novým a novým

př́ipadů, že dávání v zásadě vůbec nevyžaduje názor: čistě dané se může dovršit i bez něj. Srv. J.-L. Marion, Étant donné, str. 400-403.

36 Tamt., str. 318.

37 Proto je dokonce Marion v jednom textu označuje přívlastkem „banální“ či každodenní. Srv. J.-L. Marion, La banalité de la saturation, in: F. Bousquet - P. Capelle (vyd.), Dieu et la raison, Paris 2005, str. 169-170. Pro úplnost doplňme, že jisté typy fenoménů saturaci nepřipouštějí. Jde o tzv. chudé a běžné fenomény, jež charakterizuje v prvním př́ipadě pouze kategoriální či formální názor (matematika) a ve druhém slabý názor, nedostatečný pro to, aby mohl vyplnit nějakou intenci (technika). Srv. J.-L. Marion, Étant donné, str. 364-370.

38 J.-L. Marion, La banalité de la saturation, str. 178. 
horizontům a připravuje to, co Marion nazývá hermeneutikou, nekonečnou hermeneutikou jakožto jediným možným adekvátním ,jednáním“ vstř́c tomu, co se dává. ${ }^{39}$

Hermeneutika, nezbytná pro překonání propasti, která odděluje neviditelné od viditelného, samo jádro fenoménu spočívající v dávání od toho, jak se fenomén ukazuje, je výsostnou činností př́jemce dávání, toho, komu se dané dává (adonné), tj. subjektu definovaného čistě na základě dávání. ${ }^{40}$ Jestliže v Marionově definici fenoménu převládá názor, u takto vymezeného subjektu hraje klíčovou roli jeho receptivita, nebot' právě ona je apriorně tím, co v případě subjektu odpovídá dávání. Př́ijemce dávání (adonné) je tedy ten, kdo se otevírá hádance daného a v němž se odehrává přeměna dávajícího se na ukazující se, tj. právě hermeneutika, přeměna neurčitosti daného na viditelnou určitost, „dávání smyslu“ (Sinngebung). Vskutku jde o „dávání smyslu“, avšak nikoli ve smyslu kantovské syntézy nebo husserlovské konstituce, nýbrž s ohledem na to, co se dává:

„Hermeneutika je u daného skutečně praxí dávání smyslu, smyslu vhodného pro dané, a to tím způsobem, že se tento smysl jako takový namísto návratu do anonymity a do zákrytu osvobozuje v jeho záměrné manifestaci. Hermeneutika nedává danému smysl tím, že ho fixuje a vnucuje mu ho, ale dává mu jeho smysl, to znamená ten, který nechává jevit toto dané jako ono samo, jako fenomén, který se ukazuje o sobě a skrze sebe. “41

Dané je činěno viditelným ve struktuře výzva dávání - odpověd' manifestace: Výzva daného naráží na př́ijemce dávání, na vědomí, jako na nějaké plátno, na němž se neurčitě projektuje v podobě mlčenlivých

39 Srv. B. A. M. Kungua, Donation, saturation et compréhension. Phénoménologie de la donation et phénoménologie herméneutique: une alternative?, Paris 2005, str. 221.

40 „Adonné“ je ten, komu (à qui) se dané dává, kdo sám sebe přijímá z toho, co přijímá (z daného). Jelikož je, zdá se, nemožné francouzský termín ,adonné“ vyjádřit jednoslovným či dvouslovným českým výrazem, ponecháváme v dalším textu - po vzoru anglicky psané literatury věnující se Marionovi - vedle ne zcela adekvátního překladu „příjemce dáváni““ i původní termín. Podobně postupuje i Karel Novotný, který svůj překlad „ten, kdo je k dávání přidáván“ rovněž doplňuje originálním termínem. Srv. K. Novotný, O povaze jevi̊, Červený Kostelec - Praha 2010, str. 277.

41 J.-L. Marion, Quelques précisions, str. 229-230. 
prožitků, jako pouhá excitace čekající na to, až bude fenomenalizována. ${ }^{42}$ Je nyní na tom, kdo byl osloven a vyzván, aby odpověděl. Ovšem je třeba říct, že ona odpověd', transcendentální podmínka každé pozdější konkrétní odpovědi, začíná už sebemenší fenomenalizací výzvy, tedy ihned, jakmile se naše oči otevřou, aniž bychom se rozhodli, jestli vůbec chceme odpovídat, nebo nechceme. Termín „odpověd”“ (répons) tak u Mariona znamená nevyhnutelnou fakticitu každé naší odpovědi (réponse), jakousi původní odpovědnost, kterou je třeba ze všeho nejdřive v každém rozhodování prrijmout. Odpovědnost patři tudiž plným právem celé fenomenalitě, nikoli jen etice: Fenomenologicky je odpovědnost termínem pojmenovávajícím jistou podstatnou nutnost, která je původnější než etická odpovědnost jakožto dílčí fenomén oblasti našeho jednání. ${ }^{43}$ Instancí výzvy tedy není Druhý, Bůh, Bytí ani Život; výzva si chrání svou anonymitu, bez níž by bylo vždy jen na nějakém určitém (neredukovaném) Já, aby odpovídalo, nikoli však na prř́jemci dávání, „Já“ ve třetím pádu. ${ }^{44}$

Tato anonymita vede spolu s naší konečností $\mathrm{k}$ omezenosti našich odpovědí a ke zmíněné nutnosti odpovídat $\mathrm{v}$ rámci oné hermeneutiky bez konce. Jinými slovy, vždy pouze část z toho, co je dáno, jsme schopni dovést $\mathrm{k}$ tomu, aby se to i ukazovalo, a tak musí být hermeneutika nekončícím pohybem ukazování. ${ }^{45}$ Nicméně i dané, které je tímto způsobem opuštěno, zůstává dáno: „Př́íjemce dávání, který touží (adonné désirant), přijímá i toto opuštěné jako takové; pouze on zachraňuje krajní způsob jeho fenomenality - způsob daného, které zůstává dané i tehdy a často právě tehdy, když chybí."46 Jde vlastně o jedinou možnou adekvátní „fenomenalizaci“ v př́ípadě konečného př́ijemce: Pouze touha, protože touží po tom, co je dáno, byt' se to neukazuje, je schopna v sobě propojit rovinu viditelného s nesmazatelným přesahem neviditelného dávání.

\footnotetext{
42 J.-L. Marion, De surcroît, str. 61.
}

43 Doplňme, že z toho plyne i závaznost Marionova pojmu odpovědnosti pro každý etický pojem odpovědnosti a stejně tak i pro veškeré empirické tematizování odpovědnosti. Stejným způsobem je závazné i Husserlovo materiální a priori, podstatná fenomenální zákonitost, která je vlastním předmětem fenomenologie, první filosofie.

$44 \mathrm{~K}$ tomuto odstavci srv. J.-L. Marion, Étant donné, §§ 28-29.

45 Srv. J.-L. Marion, Reprise du donné, str. 92.

46 J.-L. Marion, Étant donné, str. 507. 
Vidíme tedy - navzdory jiné Marionově strategii, která nám umožnila zkoumat saturované fenomény -, že se jeho př́iemce dávání (adonné) nakonec nenachází př́liš daleko od Barbarasovy touhy, nebot' jde o konečný subjekt čelící neobjektivovatelné převaze fenomenálna. Pokud je ovšem subjekt konečnou touhou, pokud „dávání dává dané často bez nějaké míry, ale př́iemce dávání (adonné) v sobě nese vždy jeho meze“،,47 je $\mathrm{z}$ toho třeba vyvodit, že fenomenologický subjekt nemůže být určen pouze na základě dávání! Korelace př́ijemce dávání (adonné) - dané je, zdá se, pouhou tautologií: Jde o výraz jednoty obou pólů jevení (subjekt je určen na základě dávání věci samé), ale nikterak o výraz neodmyslitelné diference, odchylky mezi subjektem a transcendentnem, která se otevírá $\mathrm{v}$ pozici fenomenologie mezi idealismem a realismem. ${ }^{48}$

Daleko zajímavější než shoda mezi dvěma filosofy je tedy rozdíl mezi nimi, který spočívá v rozhodnutí, jež činí. Marion načrtává smělý a ambiciózní projekt, který bychom u Barbarase hledali marně: Chtěl by zkoumat základ jevení samého, dávání jakožto nejautonomnější rys fenoménu. Takový plán ovšem dostatečným způsobem nepromýšlí naši konečnost. Troufáme si říct, že Barbaras by kritizoval přesně tento bod, stejně jako to činí v př́ípadě Merleau-Pontyho a jeho „optimistické“ ontologie tělesnosti (chair), která nebyla zasažena negativitou pra-události. ${ }^{49} \mathrm{~V}$ rámci Barbarasova projektu je totiž třeba hledat aspekt nenapravitelně odděleného subjektu, a přece otevřeného dávání - a to je právě „pocit“" (ze zmíněných důvodů zřejmě vhodnější termín než „názor"), který se zdá být tím pravým místem pro zkoumání daného. V tomto ohledu by pak popis saturovaných fenoménů doplňoval - na pozadí jediného fenomenologického pole, na němž se snažíme konfrontovat tři filosofy - schéma Barbarasovo, vyplňoval by prázdné místo, které je u něj jen velmi abstraktně nadepsáno ,pra-pohyb“.

47 Tamt., str. 507-508.

48 I. Thomas-Fogiel tu podle našeho názoru správně pozoruje návrat $\mathrm{k}$ tradičnímu empirismu, v němž je subjekt vymezen svou zkušeností. I. Thomas-Fogiel, La tournure empiriste de la phénoménologie française contemporaine, in: Revue philosophique de la France et de l'étranger, 138, 2013, str. 536.

49 Viz pozn. 20. K takovému výkladu nás vede také to, že Marion - třebaže i on mluví o touze - považuje toto určení jen za odvozené z původnější figury „opuštěného“ (abandonné) jakožto jedné možnosti, kterou má př́ijemce dávání (adonné). Srv. J.-L. Marion, Étant donné, str. 507. Důvodem je to, že Marion chce ve své fenomenologii zkoumat nekonečnou konečnost (infinie finitude) subjektu: cílem hermeneutiky je rozšíření fenomenality z jednoho typu fenomenality, kterým je objektivita, na fenomenalitu (na objekt neredukovatelných) saturovaných fenoménů. Srv. J.-L. Marion, Reprise du donné, str. 186. 
Právě proto však nyní musíme završit naši prezentaci tří současných fenomenologů tím třetím, který se zdá ještě radikalizovat - ponořen do pohybu fenoménu jako nic než fenoménu - marionovský projekt. Jde o Marca Richira.

\section{Richir, fenomén jako nic než fenomén}

Jestliže se Marion pokoušel rozšířit fenomenalitu o saturované fenomény jakožto nejvhodnější výraz spontaneity fenoménu, Richir postupuje až do nejhlubší vrstvy, kde lze stále ještě fenomenologicky tuto autonomii popisovat, a to mnohem radikálněji než v prrípadě Marionovy hermeneutiky. Richir si totiž vytkl za cíl uchopit fenomén jako nic než fenomén, jít ,za“ všechno to, co je spjato s vědomím, a bádat v před-imanentní či před-intencionální rovině, nebot' pouze tam lze podle něj stopovat vlastní, absolutní „logiku“ fenoménu.

Ve vztahu k Marionovi tedy lze říct, že se jedná - na poli jakési metafyzické fenomenologie ${ }^{50}$ - o jeden z možných pokusů o rozvinutí pojmu dávání. To, co Richira zajímá, jsou neurčitosti v neviditelné hloubce fenoménu, tj. právě to, co u Mariona tento pojem skrývá. Domníváme se proto, že jde spíše o nedorozumění, které se vyjadřuje v Richirově provokativně vysloveném principu „čím více redukce, tím méně dávání (d'autant plus de réduction, d'autant moins de donation). ${ }^{51} \mathrm{Když}$ tu totiž Richir trvá na tom, že transcendentálno, Husserlův prožitek, není dáno, pak to znamená, že neexistuje „,bod, kam bychom se umístili a něco z něj ,viděli“““ 52 nebot' transcendentálno je „neredukovatelné“ (irréductible) $)^{53}$ - a to se nevylučuje s tím, co u Mariona skrývá termín „dané“ spočívající pevně na „dávání“. Dané není nikdy možné zaměnit za nějakou cele přítomnou identitu; právě kvůli záhybu dávání je vždy vysoce neurčité. A přece pořád platí, že je dáno, jelikož se nacházíme

50 R. Alexander mluví o fundamentální fenomenologické metafyzice. Srv. R. Alexander, Phénoménologie de l'espace-temps chez Marc Richir, Grenoble 2013, str. 30 .

51 M. Richir, Intentionnalité et intersubjectivité, commentaire de Husserliana XV (s. 549-556), in: D. Janicaud (vyd.), L'intentionnalité en question, Paris 1995, str. 154; M. Richir, Co je fenomén?, in: K. Novotný (vyd.), Co je fenomén? Husserl a fenomenologie ve Francii, Červený Kostelec - Praha 2010, str. 228.

52 M. Richir, Intentionnalité et intersubjectivité, commentaire de Husserliana XV (s. 549-556), str. 154.

53 Tamt., str. 162. 
v situaci „po hodu kostkami“. Dokonce i u Richira, ve vždy konkrétní části diastoly řeči ( $\mathrm{k}$ níž se dostaneme později), můžeme $\mathrm{v}$ tomto smyslu najít jakýsi ekvivalent daného - navzdory jeho velké nestabilitě. ${ }^{54}$ Proto si myslíme, že lze - na pozadí onoho jediného fenomenologického pole, do něhož oba autory situujeme - považovat Richirovu fenomenologii za radikální rozpracování místa, z něhož už Marion dál nepokračuje, tedy pojmu dávání označujícího jádro spontaneity fenoménu. ${ }^{55}$

Richir zmiňuje tento zásadní důvod své radikalizace fenomenologie: Jelikož všechno to, co intencionální prožitek implikuje, není na stejné úrovni, musí se vznést požadavek na genetickou fenomenologii, která by tyto úrovně odlišila, která by především odlišila rovinu fenomenologické základny (base), tvořenou věcí samou jakožto reziduem hyperbolické epoché, a rovinu základu (fondement) čili podmínek každé možné zkušenosti. Důvodem je, hrubě řečeno, že rovina fenomenologických konkrétností, věci samé, toho, co se nachází v samém jádru Husserlovy korelace, hra mezi jejími póly, je neustávající, nedovršený pohyb; smysl se utváŕí v rámci anonymního a vysoce dynamického procesu, a tak jeho vztah k sobě samému charakterizuje neurčitý přesah a nejde o vztah identity. Pravý fenomenologický smysl je nekonečným pohybem k sobě samému a ani fenomenologie není ničím jiným než pohybem $\mathrm{k}$ fenomenologii. ${ }^{56}$ Identita je založena až skrze Stiftung, symbolické založení, jak ř́ká Richir, což ovšem vede k transpozici, můžeme rovněž říci k ,modifikaci“ fenomenologické základny v registru intencionality. Situace totiž není zachráněna ani druhým pólem korelace: Neexistuje subjekt, který by mohl být subjektem fenomenologie jako vědy v husserlovském smyslu. Subjekt je původně rozštěpen mezi ,jác, které pozoruje to, co se

54 Ta je ve skutečnosti jediným důvodem, proč bychom měli přemýšlet o adekvátnosti termínu „dané“. Protiargumentem však bude ona distribuce fenomenálního pole, kterou jsme výše spojili s hodem kostkami.

55 Problematizujeme tedy běžnou interpretaci, která klade Richira ostře proti Marionovi. Srv. např. H. Gondek - L. Tengelyi, Neue Phänomenologie in Frankreich, Berlin 2011, str. 672; A. Schnell, La refondation de la phénoménologie transcendantale chez Marc Richir, in: Eikasia. Revista de Filosofia, 34, 2010, str. 367; R. Alexander, Phénoménologie de l'espace-temps chez Marc Richir, str. 53; nebo K. Novotný, O povaze jevů, str. 324. Zdá se nám přitom, že lze vyzdvihnout zejména dvě nedorozumění, která vedla k polemice Richira samého: 1) první se týká pojmu redukce, nebot' u Mariona se již pod tímto termínem nemíní redukce husserlovského typu, ale spíše ona „kontra-metoda“ (a Richir by jistě nepolemizoval s tím, že pro popis oné spontaneity fenoménu potřebujeme radikalizovanou fenomenologickou metodu); 2) druhé nedorozumění se týká již zmíněného pojmu daného.

56 M. Richir, De la négativité en phénoménologie, Grenoble 2014, str. 31. 
odehrává ve fenomenologické základně (což odpovídá u Husserla jeho transcendentalitě), a mezi ,já“", které je toho přímo účastno (což odpovídá jeho empiričnosti), čímž je ovšem znemožněno, aby byl pohyb kontaktu těchto dvou já kontaktem totožných já - zabraňuje tedy tomu, co Richir nazývá symbolickou tautologii (já = já). ${ }^{57}$ Jinak řečeno: nejarchaičtější vědomí, vědomí neurčitostí v hloubi Husserlovy korelace, spočívá ve slepém kontaktu se sebou samým v afektivitě. Transcendentální ego je jen iluzivní abstrakcí. ${ }^{58}$

Ovšem jak se tato dynamika vykazuje fenomenologicky, jak se smysl temporalizuje ve skutečnosti? Místo, v němž podle Richira dosáhl Husserl vrcholného bodu svého výzkumu, se nachází v pasážích Rukopisů z Bernau, kde mluví o „takovém přítomném okamžiku, jehož retence jsou ještě obývané protencemi a jehož protence jsou už obývané retencemi“". ${ }^{59}$ Proto Richir tomuto ne-intencionálnímu př́ítomnému okamžiku (prrítomnosti bez stanovitelného přítomného okamžiku) ř́ká nestabilni diastáze čili rozestup či rozdvojení. Je to právě zde, kde zanechává stopu pưvodni distorze čili podstatná neurčitost fenoménu, je to právě zde, kde se ztělesňuje utvárejicí se smysl (sens se faisant). V tomto „př́itomnu“ totiž nejsme schopni určit bod, kde se zrovna nacházíme, jelikož distorze všechny identity promíchává, čímž se jako fenomenologicky původní ukazuje pluralita. Retencionální minulost má ještě nějakou budoucnost a protencionální budoucnost má už nějakou minulost, jelikož oběma geneticky předchází hlubší architektonický registr, proto-ontologická afektivita, v níž se minulost a budoucnost díky svým transcendentálním dimenzím nepamětna (immémorialité) a nezralosti (immaturité) proplétají. ${ }^{60}$ Pokud to zjednodušíme: V té míře, v níž vposled čerpají $\mathrm{z}$ afektivity, jsou minulost i budoucnost totéž, vnitřní princip minulosti je roven vnitřnímu principu budoucnosti. Předcházení a následnost jsou již abstrakta a pouze ony dimenze nepamětna a nezralosti nám umožní sjednotit pohyb fenoménu do živoucí jednoty.

V očích Richira tudíž Husserl - tím, že nebral v úvahu architektonický dosah svých pojmů, a tím, že ho zredukoval na subjektivní prožitek - fenomén zdeformoval. Úkolem fenomenologie je sledovat jeho

57 Tamt., str. 88. Toto nachází Richir už u Husserla. Viz M. Richir, Co je fenomén?, str. 220-221.

58 M. Richir, Smysl fenomenologie, in: K. Novotný (vyd.), Co je fenomén? Husserl a fenomenologie ve Francii, str. 175.

59 M. Richir, De la négativité en phénoménologie, str. 82.

60 Tamt., str. 92. 
vlastní pohyb, a jelikož je charakterizován ne-objektivním přesahem, jsme nuceni uskutečnit hyperbolickou epoché identity. Je zapotřebí vyřadit všechny významy a objektivní reference jazyka (langue), určitostí vzešlých ze symbolického založení, díky čemuž před námi vyvstane živoucí jednota řeči (langage), která se nachází v pozadí všech jazyků. Jako u Mariona jde tak spíše o jakousi „kontra-metodu“, o maximální otevřenost spontaneitě fenoménu:

„Zlatým pravidlem metody je: nedávat si předem to, co je zapotřebi k tomu, aby ,to fungovalo ', aby se zdálo, že má vysvětlení smysl, který by byl od začátku do konce, logický. Metodou je tedy vyloučení vší pra-teleologie a objevení podstatné, byt' a priori nestanovitelné role kontingence..." 61

Prostřednictvím hyperbolické epoché se nacházíme na rovině, kde řeč žije, kde slova nemají žádný význam, jelikož jde o hádanku jejich života, o neutuchající překvapení celku konkrétna tvořeného srostlými fenomenologickými konkrétnostmi (concrétudes phénoménologiques en concrescence), „perceptivními“ fantaziemi-afekcemi (phantasiai-affections ,perceptives“). Afektivita, ono nejarchaičtější vědomí, je vždy již modulována do afekcí, které jsou však nyní díky hyperbolické epoché osvobozeny ve svém původnějším a vždy zcela konkrétním spojení s nevědomými fantaziemi, a to $\mathrm{v}$ rámci toho, čemu Richir ř́ká schematismus transcendentální interfakticity. Ten netvoří žádné určité obrazce ani figury či představy, které se již řadí k intencionálnímu vědomí (proto Richir důsledně odlišuje fantazii od imaginace), ale spíše jakési nevědomé artikulace probíhající v pozadí všech obrazců intencionality, a tedy na samém prahu znázornitelnosti. ${ }^{62}$ Fantazie je tudíž pro Richira základní „schopností“ subjektu očištěného radikalizovanou epoché (Marionova prŕijemce jevení, ,adonné“), která nám dovoluje zpř́ítomnit to, co prrítomné není - jde o vlastní schopnost ne-intencionální fenomenologie. ${ }^{63}$

Všechny sebemenší změny uvnitř tohoto živoucího těla řeči, každé vynoření afekce je následně pocítěno v našem „vnitřním prostoru“ skrze

61 Tamt., str. 197-198. Zvýraznil P. P.

62 Srv. A. Schnell, Le sens se faisant, Marc Richir et la refondation de la phénoménologie transcendantale, Bruxelles 2011, str. 98.

63 Proto Richir v narážce na Merleau-Pontyho hovoří o „primátu“ fantazie. Viz M. Richir, L'écart et le rien, conversations avec Sacha Carlson, Grenoble 2015, str. 176. 
kinesteze, a můžeme i dodat: skrze naši tělesnost (chair). Toto vskutku odpovídá tomu, co Merleau-Ponty označuje za jeden z rysů svého pojmu neviditelna (jehož radikální rozpracování nám nabízí Richir): Neviditelno existuje taktilně či kinesteticky. ${ }^{64}$ Jde tu o tělesné pocit’ování neviditelných fantazii-afekcí, jež tvoří naši konkrétně žitou ne-intencionální přítomnost, o pocit'ování vlastního pohybu fenoménu jako nic než fenoménu. Kinesteze mu však odpovídají pouze ve svém živoucím celku. Pohybu fenoménu neodpovídá ten či onen tělesný pocit, tj. např. Husserlovy konkrétně lokalizované počitky při dotýkání jedné ruky tou druhou. Fenomén jako nic než fenomén lze „spatřit"“ jen v živoucí jednotě všeho takového pocit’ování, v níž nedochází k žádné abstrakci jednotlivých počitků, nýbrž k jejich vzájemnému prolínání (pouze takto jsou fantazie-afekce ,perceptivní“ - vnímají samy sebe navzájem a zároveň jsou vnímány ,subjektem“ v jejich konkrétnosti). Proto lze tuto jednotu popsat jako jakési „tempo“ našeho vnitřního prostoru: ,jestliže se celek kinestezí konkrétně dovrší v živoucí jednotě, konstituuje tempo ,vnitřního prostoru““, v němž se „ne-intencionální př́ítomnosti ... udržují jen skrze jiné a jako jedny v druhých, v lůně toho, o čem tušíme, že je to jejich ,překlad“ schematismu ... jako fenoménu a nic než fenoménu“. 65

Hlavním úkolem fenomenologie je sledování tohoto pole nestabilit či neurčitostí, hledání jeho tempa a nacházení správného výrazu pohybu fenoménu. Na rozdíl od hudby či poezie, která toho dosahuje tekutostí slov, ${ }^{66}$ nemá ale fenomenologie jiný prostředek než specifický filosofický nástroj: architektoniku. Ačkoli jsme vstoupili do před-intencionální oblasti plné pohybu a neurčitostí, která se nachází v podzemí běžného jazyka a srozumitelnosti, neznamená to, že by se možnost fenomenologie měla vstříc tomuto chaosu rozplynout: Vlastní fenomenologické pole je popsatelné prostřednictvím rozlišení několika architektonických genetických vrstev, mezi nimiž se fenomén pohybuje, které se nicméně nepřekrývají - v celku si celý systém myšlení představit či reprezentovat

64 Jde o třetí aspekt neviditelna podle jedné pracovní poznámky v M. Merleau-Ponty, Viditelné a neviditelné, přel. M. Petř́iček, Praha 1998, str. 250.

65 M. Richir, De la négativité en phénoménologie, str. 85.

66 Básník musí podle Richira hledat taková slova, která jsou ozvěnou fantazii-afekcí, toho, co ve své konkrétní singulární životní zkušenosti prožil a o čem chce psát, pročež jde o slova, jimž nelze přidělit pevný význam. Aby mohl být zachycen pohyb fenoménu, všechna slova básně se musí navzájem prolínat. Jako extrémní příklad Richir uvádí Rimbauda, u něhož jsou samohláskám přiřazovány barvy. Srv. tamt., str. 100. 
nemůžeme. ${ }^{67}$ Proto Richir hovoří metaforicky o tom, že se fenomén jako nic než fenomén mezi všemi genetickými registry mihotá. V nové transcendentální fenomenologii je třeba všechny tyto registry rozlišit a ukázat mezi nimi místo zkušenosti přrirozeného postoje. ${ }^{68}$ To je jediný možný a důsledný způsob, jakým lze porozumět světu našeho života - což je, dodejme, poslední motiv toho, že Husserl uskutečnil epoché a dospěl $\mathrm{k}$ fenoménu světa. Architektonická struktura proto není nic jiného než radikální fenomenologické rozpracování fenoménu světa. Přitom je třeba ukázat, jak jsme již naznačili výše, že jde o pluralitu tzv. světských fenoménů (phénomènes-de-mondes), která zajištuje životnost jediného světa našeho života. ${ }^{69}$

Prozatím jsme hovořili o dvou registrech: 1) svět našeho života, zkušenost konstituovaná husserlovskou transcendentální subjektivitou na základě universálního korelačního a priori, které můžeme ř́́kat jednoduše intencionalita nebo kladoucí doxa, díky níž se nacházíme na rovině, na níž mluvíme o jsoucnech či věcech; 2) archaičtější registr neurčitých a nestabilních ,perceptivních“ fantazií-afekcí, registr vždy již schematizované afektivity pocit’ované skrze kinesteze.

Abychom však mohli dostatečně artikulovat problém světských fenoménů, které jsou vlastní transcendencí tohoto registru „perceptivních“ fantazií-afekcí (transcendencí - čili tím, co se v nich jeví - není jediný svět, ale pluralita světů), musíme nejdříve hovořit o jiném registru, v němž najdeme počátek schematizace afektivity, tedy vlastně toho, že existuje fenomenologie jakožto ona střední pozice mezi imanencí a transcendencí - o ,momentu “ vznešena. Fenomenologickým motivem této teorie „momentu“ vznešena je totiž jistý neredukovatelný fenomenologický přesah nad celkem konkrétna afekcí (lze říct: nad imanencí), nadbytek nad naší afektivitou zaprríčiněný tím, že afektivita nekonstituuje fenomény zcela sama: Fenomenologie se nachází mezi imanencí (afektivitou) a transcendencí, jejíž role je v konstituci klíčová. Jinými slovy, smysl (řreč) musí být smyslem něčeho jiného, než je on sám, něčeho mimo řě (hors langage). ${ }^{70}$

Proto je zapotřebí popsat pohyb fenoménu i s ohledem na transcendenci, a právě to je náplní teorie „momentu“ vznešena. I v tomto typu

67 M. Richir, L'écart et le rien, str. 198.

68 Tamt., str. 124.

69 Srv. M. Richir, Autant de chantiers ouverts à l'analyse que de questions pour la condition humaine, in: Magazine littéraire, 403, 2001, str. 61.

Srv. M. Richir, L'écart et le rien, str. 174. 
popisu je však nutné zůstat na půdě fenomenologie, a proto jde o popis transcendence vzhledem $\mathrm{k}$ afektivitě, vzhledem $\mathrm{k}$ tomu, jaké stopy v ní transcendence zanechává. Jako je tomu u našeho srdce, i v pohybu fenoménu lze podle Richira odlišit dva momenty: 1) moment diastoly řeči, z hlediska fenoménu jakéhosi klidového stavu, poté co byly kostky vrženy, kdy došlo k distribuci fenomenálního pole (ke schematizaci afektivity v „perceptivních“ fantaziích-afekcích), v jistém smyslu tedy dokonce „daného“ stavu (byt' v žádném případě ,jsoucího“); tomuto momentu však předchází 2) moment systoly, výraz životní moci afektivity, její nadbytek v takové extrémní koncentraci a intenzitě, že dochází - v „momentu“ vznešena - $\mathrm{k}$ jejímu rozštěpení. ${ }^{71} \mathrm{Zjednodu-}$ šeně lze říct, že se naše afektivita, dosud pouze množství životní síly, probouzí, a my jsme skutečně afikováni. Afektivita se přitom rozštěpuje v té míře, v níž do ní vstupuje jistá minimální distance: Jedině tak může fenomenolog pozorovat, jak se afektivita schematizuje, jedině tak je afektivita v kontaktu se sebou samou. A tento minimální odstup je spjat právě s transcendencí: Jakmile jsme afikováni, tj. naše afektivita je modulována do afekcí, znamená to, že nezastavitelně počíná unikat transcendence. Jakmile dochází ke schematizaci afektivity čili ke „konstituci“ fenoménu, transcendence je vedle afektivity (patř́ící spíše na stranu imanence) druhým korelujícím pólem. Neznamená to však, že by Richir postuloval cosi skrytého „,za“ hranicemi fenomenologie, „za“ pohybem fenoménu: Unikání tzv. absolutní a nevztažné transcendence, k němuž dochází od „momentu“ vznešena, je jen důsledným popisem základního fenomenologického faktu, že se něco jeví tak, že se v tomto jevu nevyčerpává - že se jeví transcendence. Richirův „moment“"vznešena tak míŕí na totéž, na co poukazuje Barbarasova pra-událost: Jde v něm o separaci subjektu, o nutný minimální odstup pro to, aby mohl být místem fenomenalizace.

Unikání absolutní transcendence je tedy jakýmsi velmi formálním a prázdným pra-faktem fenomenologie, který však nelze obsahově nějak blíže vymezit (proto je „nevztažná“). To, co tvoří vlastní transcendenci registru ,perceptivních“ fantazii-afekcí, a co tudíž lze obsahově uchopovat, to, co se ve vlastním smyslu jeví, je fyzicko-kosmická transcendence, svět jakožto poslední referent sféry jevení, který však musí být vzhledem

71 Ve své psychoanalytické interpretaci, inspirované hlavně Winnicottem, tedy již za hranicemi fenomenologie, Richir tuto intenzifikaci afektivity, která končí humanizací dítěte, vysvětluje láskou jeho matky. Srv. M. Richir, De la négativité en phénoménologie, str. 140. 
k pohybu fenoménu a nemožnosti identifikace pojímán pluralitně jako již zmíněné světské fenomény.

Zopakujme tedy, že transcendence má nutně dva aspekty: 1) absolutní transcendence jakožto minimální a neproživaná diference (požadovaná i Barbarasem), vykazatelná pouze skrze zvraty retencí v protence a naopak - „moment“ vznešena; 2) transcendence jakožto jakýsi obsahový doplněk nevztažné absolutní transcendence, fyzicko-kosmická transcendence, referent fantazií-afekcí, svět ve svém archaickém fenomenologickém smyslu. Schematismus řeči (,perceptivních“ fantazii-afekcí) je pouhou ozvěnou či opakováním schematismu archaičtějšího - schematismu světských fenoménů. Světské fenomény tudíž nejsou žádné znázornitelné (intencionální) figury ani objekty, ale spíše jejich měnící se pozadí odpovídající zvratům transcendentální minulosti a budoucnosti, které $\mathrm{v}$ př́ípadě snahy o fixaci unikají. Tyto fenomény tvoří dohromady svět jakožto referent afektivity, jakousi proto-fázi či němou proto-prŕítomnost světa (v tomto registru nejde o svět našeho života, ale o jeho fenomenologickou bázi). Jde o pluralitu „divokých esencí“ (Wesen sauvages) světa, o jakési esence v hlubině těch Husserlových, v pozadí jeho pasivních syntéz, esence konkrétních částí naší tělesnosti (chair), které udržují schematismus koherentní: azurová modř nebe jakožto rezonance jiné modře, pozorované jindy. ${ }^{72}$

Jestliže lze tedy u Richira mluvit o nějaké korelaci, pak je to především korelace fenoménů řeči a světských fenoménů (fyzicko-kosmické transcendence). Tato korelace se nachází v hloubce korelace Husserlovy a mohli jsme ji objevit jen díky radikální hyperbolické epoché. Podle Richira je tak nutné lehce korigovat to, co jsme dosud řekli o subjektu a světu: Určením subjektu je sice opravdu touha, ale její podstatou je Erós, neukojitelná aspirace, která se ve schematismu fyzicko-kosmické transcendence modifikuje na (Barbarasovu) touhu po „správném výrazu“ pohybu fenoménu. Svět jakožto ,jsoucí-dané v celku“ je pak s ohledem na nejméně uchopitelný aspekt „dávání“ rozpracován v podobě téhož registru světských fenoménů, úzce spjatého s únikem absolutní transcendence. A konečně musíme poopravit i pojmenování důvodu naší separace, podmínku fenomenalizace světa subjektem, která je událostí jen iluzorně, nebot' neexistuje okamžik, $v$ němž bychom pohyb fenoménu mohli zastavit a jakoukoli událost fixovat. ${ }^{73}$

72 Srv. M. Richir, L'écart et le rien, str. 177-182.

73 Srv. M. Richir, De la négativité en phénoménologie, str. 174-178. 
Zbývá nám tak stále ještě úvaha o tom, zda je tento průzkum fenoménu jako nic než fenoménu - když vezmeme v úvahu to, co bylo řečeno o korelaci - fenomenologicky legitimní. Ačkoli totiž Richir říká, že žádný z registrů není první, že je nejarchaičtější registr pouhou hyperbolou, křižovanou vždy již kontra-pohybem, zároveň dodává, že symbolické založení, a tedy i velká část intencionality, nemá fenomenologický původ. ${ }^{74}$

\section{Závěr: Post-klasická eidetika a nebezpečí prázdného formalismu}

Vztah Richirovy korelace schematismu řeči a schematismu světských fenoménů $\mathrm{k}$ intencionalitě nám ukazuje architektonika obsahující vedle vlastního fenomenologického registru ,perceptivních“ fantazii-afekcí i registr, v němž dochází k přerušení pohybu utvářejícího se smyslu, ${ }^{75}$ a tudíž prímou cestu $\mathrm{k}$ registru intencionality, v němž najdeme i ne-fenomenologické prvky (tj. symbolické založení). Intencionalita myšlená ve vztahu k registru fenomenologické základny je totiž pouhá transcendentální iluze jdoucí proti pohybu utvářejícího se smyslu. Tento ne-fenomenologický charakter intencionality je však velmi problematický, a to nejen proto, že takto by Husserlova fenomenologie ze své větší části vůbec fenomenologií nebyla. I když se nakonec na pozadí jediného fenomenologického pole, na němž zde pracujeme, může zdát, že se Richir takové námitce vyhýbá, jelikož jeho architektonika popisuje celé pole myšlení, tj. včetně intencionality, upřednostnili bychom přesto Husserlovo používání slova „fenomenologický“. Vždyt' platí, že to, co po nás požaduje hyperbolická epoché, je enormní úsilí, během něhož z velké části ztrácíme sami sebe, a to ve prospěch fenoménu jakožto jisté abstrakce ze všeho toho, co se jeví. Richir vylučuje z definice fenoménu identitu a intencionalitu (přinejmenším hovoří o iluzi náležející $\mathrm{k}$ fenoménu), protože radikálně rozpracovává logiku jisté odchylky (nestabilní diastáze, tj. jednoho, a to nejméně nápadného prvku) ve všem tom, co se jeví (po husserlovské epoché). Přesně to je pro něj fenomenologie: žádná triviální korelace dvou abstraktních pólů, nýbrž to, co se děje „mezi“. Richir doplňuje Husserlovu epoché o redukci míŕící skrze

74 M. Richir, L'écart et le rien, str. 35-39.

75 O tomto registru, který je pro účely tohoto článku nejméně důležitý, jsme nehovořili. Srv. M. Richir, De la négativité en phénoménologie, str. 71-72. 
suspenzi jediné stability korelace vstříc dynamice, která je podle něj vlastním objevem fenomenologie. Proč? Protože v naší konkrétní zkušenosti nic stálého není a její jistá část se nám pořád ztrácí, uniká. ${ }^{76} \mathrm{~S}$ tím je třeba souhlasit, ale vzápětí musíme dodat, že se neztrácí vše. Ono „mezi“" totiž není jen nekonečný únik: I když suspendujeme identitu, všechny významy jazyka, není jasné, proč bychom měli jakoby znovu redukovat to, co zbývá (nebot' to, co zbývá, není symbolicky založené, to bylo redukováno), a situovat právě a jen do nestabilní diastáze jádro fenoménu. Rozumíme tomu jen potud, pokud jde o rozšíření fenomenality. Nelze pochybovat o tom, že fenomenologie musí být radikální, a to až do té míry, že uskutečňuje tuto Richirovu redukci - jen tak totiž dojde k opravdovému rozšíření jejího pole. Rovněž je však nutné si uvědomit, že jde o rozširření a nikoli o pole celé. Domníváme se tedy, že „fenomenologické“ “ je vše to, co je žito, tj. nejen jeho genetická hloubka, ale i to, co se nachází na povrchu a co je iluzí jen ve slovníku čerpajícím z oné nepatrné odchylky. Zde se podle našeho názoru nachází oprávnění pojmu „daného“ u Mariona, jenž ve snaze říci cosi o neurčitostech v jádru fenoménu odkazuje na pojem dávání, aniž by současně s tím opustil pojem daného.

Ačkoli tedy Richir uniká problému asymetrické korelace, protože autonomii fenoménu neprripisuje jednomu z pólů korelace, jeho verze fenomenologické korelace je jaksi př́liš lehká, než aby dovedla unést celou tíhu fenomenologie založené na definici fenoménu u Husserla. V tomto ohledu jsou Barbaras s Marionem Husserlovi mnohem blíže. Přes tento a jiné rozdíly, na něž jsme se pokusili poukázat, lze však nakonec konstatovat, že se v rámci onoho jediného fenomenologického pole, na němž jsme je konfrontovali, všichni doplňují: Barbaras klade zejména otázku po způsobu bytí subjektu, zatímco Mariona a Richira zajímá spíše to, co se subjektu jeví. Každý přitom postupuje s jiným stupněm radikálnosti v bádání po jevení samém. Richir radikalizuje fenomenologii až do toho bodu, kdy je v jeho očích nezbytné ji definovat jinak - jako fenomenologii zabývající se fenoménem jako nic než fenoménem. Proto může rovnováhu klasické korelace zajistit jen $n e$-fenomenologickými prvky.

Abychom ale mohli naši úvahu uzavřít, musíme si ještě připomenout, že otázka korelačního a priori u Husserla nevyčerpává fenomenologické tázání. Ačkoli jí opravdu zasvětil svůj život, její zodpovězení je podle něho pouhou první částí řešení krize, kterou ve svém pozdním díle diagnostikoval. Odkrytí absolutní subjektivity totiž zároveň dává nový

76 M. Richir, L'écart et le rien, str. 127. 
smysl naší existenci v prostoro-časovém světě, znamená pro nás úkol žít svioj konkrétní život v apodikticitě:

„Nový smysl dále dostává i nejzazší sebepochopení člověka, odpovědného za své vlastní lidské bytí, jeho sebepochopení jako bytí povolaného k životu v apodiktičnosti, nikoli jen abstraktně k tomu, aby vybudoval apodiktickou vědu vobvyklém smyslu, nýbrž aby realizoval takovou vědu, která uskutečňuje veškeré konkrétní bytí lidstva v apodiktické svobodě tak, aby bylo apodiktické, jediné ve všem činném životě rozumu, který působí, že je lidstvo lidstvem.“"77

Tuto myšlenku nalezneme i v samém programu Husserlovy fenomenologie, jenž se odráží např̀. v rozdělení všech svazků jeho Idejí, kdy druhý a třetí díl svědčí o nezbytném fenomenologickém pohybu od eidetiky $\mathrm{k}$ empiričnu: totiž $\mathrm{k}$ empiričnu založenému fenomenologicky. ${ }^{78}$ A právě zde vidíme jádro kritiky formulované $M$. Henrym, která je podle našeho mínění zcela oprávněná a která se týká všech fenomenologů, jimž jsme se věnovali: Fenomenologie radikalizující epoché či redukci není nakonec ničím jiným než prázdným formalismem. ${ }^{79}$ My bychom chtěli tuto námitku shrnout pod termín post-klasická eidetika. Ačkoli např. Barbaras uspěl ve svém pokusu založit svět našeho života fenomenologicky, tj. ve svém pojmu pra-pohybu, a ačkoli jeho dílo obsahuje nespočet pasáží, v nichž se věnuje vztahu fenomenologie a empirických věd, přesto je jejich založení prostřednictvím pouze formálního, abstraktního určení živého, kterým je touha, nedostatečné. Podle našeho názoru, a to ve směru toho, o čem hovoří Husserl, je nutné klást i tyto otázky: Jaké jsou empirické důsledky toho, že je vědec touhou a jeho objekt je součástí

77 E. Husserl, Krize evropských věd a transcendentální fenomenologie, str. 295. Zvýraznil P. P.

78 Ve svém dopise adresovaném K. Joelovi Husserl dokonce přiznává, že by raději provozoval „druhou filosofii“ a že se s eidetikou spokojuje pouze dočasně. Srv. R. Bernet - I. Kern - E. Marbach, Úvod do myšlení Edmunda Husserla, přel. P. Urban, Praha 2005, str. 249. Zároveň je nade všechnu pochybnost, že je druhá filosofie, přinejmenším částečně, stále fenomenologickou disciplínou, nebot' vědy se nedovedou založit samy. K tomu srv. např. E. Husserl, Idées directrices pour une phénoménologie et une philosophie phénoménologique pures, III, Paris 1993, str. 28; nebo E. Husserl, Karteziánské meditace, přel. M. Bayerová, Praha 1993, str. 146-149.

79 M. Henry, Quatre principes de la phénoménologie, in: týž, De la phénoménologie, Paris 2003, str. 104. 
pra-pohybu světa? Jak může být vědec věren svému transcendentálnímu určení a dělat vědu založenou fenomenologicky?

Pokud Husserl proti sobě staví první filosofii, eidetiku, a druhou filosofii, vědu o universu faktů, musíme konstatovat, že Barbarasova fenomenologie života je eidetikou. Tím ovšem neř́íkáme, že by jeho Dynamika manifestace byla eidetikou v husserlovském smyslu: Jeho radikalizovaná epoché nemá za cíl vědomí a jeho eidé, ale jevení v jeho autonomii, ${ }^{80}$ tj. snaží se popsat jiné esence konstituující fenomén, což je v první řadě odstup, post-klasická esence par excellence. ${ }^{81}$ Post-klasická eidetika je tedy fenomenologický způsob, jímž je uchopena autonomie fenomenálního pole, což je možné pouze za pomoci tak extrémně formálních či širokých pojmů, že jsou schopny v sobě obsáhnout veškerý pohyb fenoménu i se všemi jeho minimálními změnami. $Z$ tohoto pohledu můžeme pod tento termín zahrnout i Marionovo „dávání“ a Richirovy ,architektonické registry“, byt’ Richir opakuje, že o žádnou eidetiku nejde - nejde o eidetiku v husserlovském smyslu, nýbrž o post-klasickou eidetiku několika genetických rovin.

Husserl chtěl návratem k věcem samým otevřít svět našeho života, proto je zcela nezbytné se k tomuto světu (našemu běžnému empirickému žití) od věcí samých (od post-klasické eidetiky) vrátit, založit ho fenomenologicky, byt' je nepochybné, že toto založení bude vypadat jinak, než se domníval Husserl. Námi vybraní autoři však svou eidetiku dostatečným (jelikož jsou tu jisté tendence, hlavně Marionovy analýzy saturovaných fenoménů a jeho hermeneutika) návratem nedoplňují. U Richira se zdá zcela převažovat anarchický rys fenomenologie: empirický svět je iluzí. Domníváme se však, že musíme klást další otázky: Žijeme někdy či lze alespoň částečně žít bez této iluze, tj. na základě vlastního fenomenologického registru fantazií-afekcí? Jestliže je úkolem umělce jazyková (langue) artikulace těchto konkrétností, není to nakonec úkol každého člověka bez výjimky? Tím spíše, že Richir přebírá krásný Maldineyho př́klad a popisuje setkání dvou starých přátel, mezi nimiž ovšem až jednoho dne dojde k opravdovému vcítění, jedinému ryzímu porozumění druhému na základě toho, co prožíváme na rovině žité jednoty pohybu fenoménu. Ačkoli o tom dále nemluví, toto porozumění

80 R. Barbaras, Sauver d'une réification de la conscience. La tâche de la phénoménologie, str. 50.

81 První kniha, kde Barbaras hovoří obsáhle o touze, se jmenuje Touha a odstup, přel. J. Fulka, Praha 2005. Později byl však pojem odstupu dále rozpracován a zrodily se pojmy pra-pohybu a pra-události. 
bude zcela jistě následováno patřičným chováním ve všech sférách jejich vzájemného vztahu, tj. i v tom, co je symbolicky založeno! Jestliže ale to, o co v životě jde (troufáme si říct „etika“, protože o ni tu s ohledem na výše zmíněný Marionův pojem původní odpovědnosti běží), tímto způsobem překračuje založené směrem $\mathrm{k}$ jevení samému, musíme formulovat následující otázku: Jak můžeme odpovidat událostem jevení? Tato otázka je pro nás shrnutím celé diskuse o universálním korelačním a priori, včetně toho, co po ní podle Husserla musí následovat. S pomocí Barbarasových pojmů bychom otázku položili ještě jinak: Jak může subjekt jakožto separovaná bytost (intencionální, pojmová, objektivujicí) a současně bytost přináležející k jevení samému (skrze pocit u Barbarase, skrze saturovaný názor u Mariona, skrze fantazii u Richira) žit fenomenologicky? Jak bychom mohli posunout úvahy o universálním korelačním a priori na rovinu konkrétní korelace, na rovinu nějakého konkrétního fenoménu empirických věd, nebo jakéhokoli konkrétního fenoménu našeho každodenního života? Jakým způsobem bychom mohli provozovat fenomenologii, která by nakonec nebyla jen prázdným formalismem? ${ }^{82}$

\section{RÉSUMÉ}

L'article commence par une interprétation du projet phénoménologique de R. Barbaras qui poursuit de manière conséquente la « logique » de la corrélation phénoménologique. Dans l'œuvre de J.-L. Marion, présentée dans la deuxième partie du texte, on peut identifier une sorte de rupture de son équilibre, correspondant à la recherche des phénomènes saturés. Néanmoins, la phénoménologie de M. Richir, dans sa tentative de saisir le mouvement du phénomène comme rien que phénomène au niveau pré-intentionnel, est encore plus radicale et peut être considérée comme une élaboration de la notion marionienne de donation. Dans la conclusion, tous les trois projets sont désignés comme " eidétique post-classique » qui ne devrait pas être le dernier mot de la phénoménologie basée sur la corrélation de Husserl.

82 Tento článek vznikl v rámci projektu „Subjekt jako setkání - subjekt v událostním světě“, č. 42615, řešeném v roce 2015 na Filozofické fakultě Univerzity Karlovy v Praze z prostředků Grantové agentury UK, hlavní řešitel Petr Prášek. Za všechny připomínky a návrhy na vylepšení textu děkuji redakci časopisu Reflexe a Elišce Luhanové. Za pročtení první verze textu děkuji A. Šimkovi. 


\section{SUMMARY}

Part I provides an interpretation of Renaud Barbaras' phenomenological project in which he pursues the "logic" of the phenomenological correlation. In the work of J.-L. Marion, as shows the second part, one can identify a sort of disruption of its equilibrium corresponding to Marion's inquiry of saturated phenomena. However, Marc Richir's phenomenology, in its attempt to follow the movement of the phenomenon as such on pre-intentional level, is even more radical and can be considered a further elaboration of Marion's "givenness" (donation). In the conclusion, all three projects are designed as "post-classical eidetics" which should not be the last word of phenomenology based on Husserl's correlation. 